\title{
URL Data Type
}

National Cancer Institute

\section{Source}

National Cancer Institute. URL Data Type. NCI Thesaurus. Code C95829.

A data type comprised of a uniform resource locator. 